\title{
Long-term interannual cycles of the gametogenic ecology of the Antarctic brittle star Ophionotus victoriae
}

\author{
Laura J. Grange ${ }^{1, *}$, Paul A. Tyler ${ }^{1}$, Lloyd S. Peck ${ }^{2}$, Nils Cornelius ${ }^{1}$ \\ ${ }^{1}$ School of Ocean and Earth Science, SOC, University of Southampton, Southampton SO14 3ZH, UK \\ ${ }^{2}$ British Antarctic Survey, High Cross, Madingley Road, Cambridge CB3 0ET, UK
}

\begin{abstract}
Spermatogenesis, oogenesis and fecundity are described and the gonad index calculated for 10 individuals from each month using histological and image analysis techniques for the Antarctic brittle star Ophionotus victoriae (Bell 1902). Individuals were collected between September 1997 and December 2000 from a shallow water population (15 to $20 \mathrm{~m}$ ) on the west of the Antarctic Peninsula. Both male and female gonad index varied seasonally, where proportions of large oocytes and mature sperm decreased markedly between November and December of each year, indicating the spawning period. Although the annual timing of reproduction was consistent among years, $O$. victoriae displayed considerable inter-annual variation in reproductive effort. This variability was notable in the gonad and gut index of both males and females and in female fecundity, which showed no discernible change in some years, but varied more than an order of magnitude in others. We identify 3 main aspects to the reproductive ecology of $O$. victoriae: (1) spawning was synchronous and annually consistent; (2) long periods were required for gamete development, with oocytes requiring $\sim 18$ to 24 mo to mature; (3) there was clear inter-annual variability in reproductive effort and nutritional condition, which could be associated with the extent of the preceding organic sedimentation event. Subsidiary effects may also have been felt from the seasonal ice profile and temperature signal. A combination of all or some of these patterns may be an adaptation to the distinct seasonality and low level resource supply characteristic of the Antarctic and the long-term cycles intrinsic in polar environmental variables.
\end{abstract}

KEY WORDS: Inter-annual variation - Reproductive effort - Sedimentation events - Antarctica · Ophionotus victoriae

Resale or republication not permitted without written consent of the publisher

\section{INTRODUCTION}

The waters round the Antarctic have low but stable background temperatures set against a highly seasonal food regime (Lipps \& Hickman 1982, Clarke et al. 1988, Dayton 1990, Clarke \& Leakey 1996). During the austral winter seawater temperatures drop to $-1.9^{\circ} \mathrm{C}$ and the sea-surface is frozen, whereas summer water temperatures may rise to $>1.0^{\circ} \mathrm{C}$. As a result of this stenothermal environment, energy input has a profound ecological effect. An intense seasonal signature in light and sea ice cover stimulates the very marked seasonality in surface primary production (Clarke
1988), where the pulse of organic matter to the local seabed is temporally constrained.

Polar reproductive patterns typically have a long duration and gametogenic development is slow (Hedgpeth 1971). However, it may not be the low temperatures per se that restrict Antarctic marine invertebrates (Pearse et al. 1991), but the seasonal pattern in food availability (Clarke 1982). The latter has been assumed responsible for Antarctic spawning frequencies and magnitudes (Giese 1959). However, a more recent multivariate analysis indicates temperature as the most important environmental factor controlling developmental rates (Hoegh-Guldberg \& Pearse 1995). 
Mortensen (1936) and Thorson (1950) found a high incidence of brood protection in Arctic invertebrates, and Mileikovsky (1971) suggested this as a general rule. Much of this was attributed to the paucity of planktonic food (Chia 1974). However, more recently, a common occurrence of pelagic feeding and nonfeeding reproductive strategies has been documented in invertebrates (Pearse 1994, Pearse \& Bosch 1994). Thereafter, the current number of larval types in Antarctica has been shown to be high (Stanwell-Smith et al. 1999) in contrast to the earlier Arctic studies from the 1950s and 1960s. This suggests that Thorson's rule might apply only to the Arctic.

High Antarctic shallow waters are often dominated by the Echinodermata, especially the echinoid Sterechinus neumayeri, sea star Odontaster validus and ophiuroid Ophionotus victoriae (Pearse 1994, ManjónCabeza \& Ramos 2003). The substantial occurrence of ophiuroids in extreme environments with highly seasonal food regimes signifies this taxon's ecological flexibility and energetic importance (Gage \& Brey 1994, Emson 1999). Reproduction of ophiuroids has been reviewed most recently by Hendler (1991) and Byrne (1994), whilst the ecological specificities of Antarctic ophiuroids have been addressed by Dahm (1996). Brittle star spawning and reproductive strategies are extremely diverse (Hendler 1991), and this plasticity has been coupled with variable environmental conditions (McGinley et al. 1987, Hadfield \& Strathmann 1996). In Antarctica, gametogenic periodicity in echinoderms other than ophiuroids has been determined for S. neumayeri (Brockington 2001) and for O. validus (Pearse 1965), both of which spawn annually, but require 18 to 24 mo for gametogenesis. However, the reproductive biology of high Antarctic ophiuroids is unknown except for remarks in major taxonomic works (Mortensen 1936).

Ophionotus victoriae is circumpolar and 5-armed, and has a wide distribution throughout the high Antarctic in the Ross Sea and along the Antarctic Peninsula. This ophiuroid is known to characterise some macrobenthic assemblages within these regions sometimes surmounting to the second most important taxon in terms of numbers (Sáiz-Salinas et al. 1997, Arnaud et al. 1998). It inhabits a variety of substrata (level mud to gravel and rock bottoms) and ranges between 5 and $1266 \mathrm{~m}$ depth (Madsen 1967). The diet of O. victoriae is also very catholic (Dearborn 1977, Fratt \& Dearborn 1984), and large O. victoriae even appear to be cannibalistic on small individuals of its own species. This suggests that ophiuroids have a high dietary plasticity, allowing the exploitation of habitats where the seasonal availability of food is changeable and varied. O. victoriae is oviparous (Koehler 1912) and Mortensen (1936) described the eggs as 'small and numerous', suggesting that they produce a typical ophiopluteus larva.

A few studies of reproductive cycles have been reported from Antarctic species using monthly samples over a 1 to $2 \mathrm{yr}$ period. Some of these have shown considerable inter-annual variation in reproductive effort, e.g. Liothyrella uva (Meidlinger et al. 1998) and Adamussium colbecki (Chiantore et al. 2002). The Southern Ocean is characterised by environmental variation on a range of frequencies. One of the most recently described of these is the 'Antarctic Circumpolar Wave' (White \& Peterson 1996), in which a dipole variation in sea ice extent moves round the Antarctic. There is also considerable debate as to whether the waters round Antarctica are being affected by global warming (Vaughan et al. 2001). The stenothermal character of polar invertebrates makes them highly susceptible to temperature change; thus, these invertebrates are likely to be amongst the most vulnerable species worldwide to environmental modifications (Pörtner et al. 1999, Peck \& Conway 2000, Pörtner 2002, Peck unpubl.). Reproductive success is a key characteristic in this respect and evaluation of change in reproductive effort with time key to identifying vulnerable taxa.

The aim of this paper was to: (1) evaluate the seasonal reproductive periodicity and reproductive effort over a 3 yr period in Ophionotus victoriae; (2) compare inter-annual variation in reproductive characters; and (3) relate cycle characteristics to variance in the local physico-chemical environment.

\section{MATERIALS AND METHODS}

Sampling. This long-term study was undertaken at the British Antarctic Survey's Rothera Research station (Fig. 1) on Rothera Point, Adelaide Island, to the west of the Antarctic Peninsula $\left(67^{\circ} 34^{\prime} \mathrm{S}, 68^{\circ} 08^{\prime} \mathrm{W}\right)$. The sampling area is characterised by a predominantly cobble bottom with rocky boundaries, including a soft bottom area at Hanger Cove.

Specimens of Ophionotus victoriae were collected by SCUBA divers at 15 to $20 \mathrm{~m}$ depth from either North Cove or Hanger Cove between September 1997 and December 2000. A minimum of 10 adult individuals were collected randomly each month, with the exception of January 2000 where only 8 individuals were collected (disc diameter $>10 \mathrm{~mm}$ ). Monthly samples were taken with the exception of April and June 1999, when poor weather precluded sample collection. Once collected, samples were preserved in $4 \%$ formalin for transport and subsequent storage in England.

An environmental monitoring programme is also maintained at Rothera that compiles, on average, weekly recordings of temperature (by a SIS reversing 

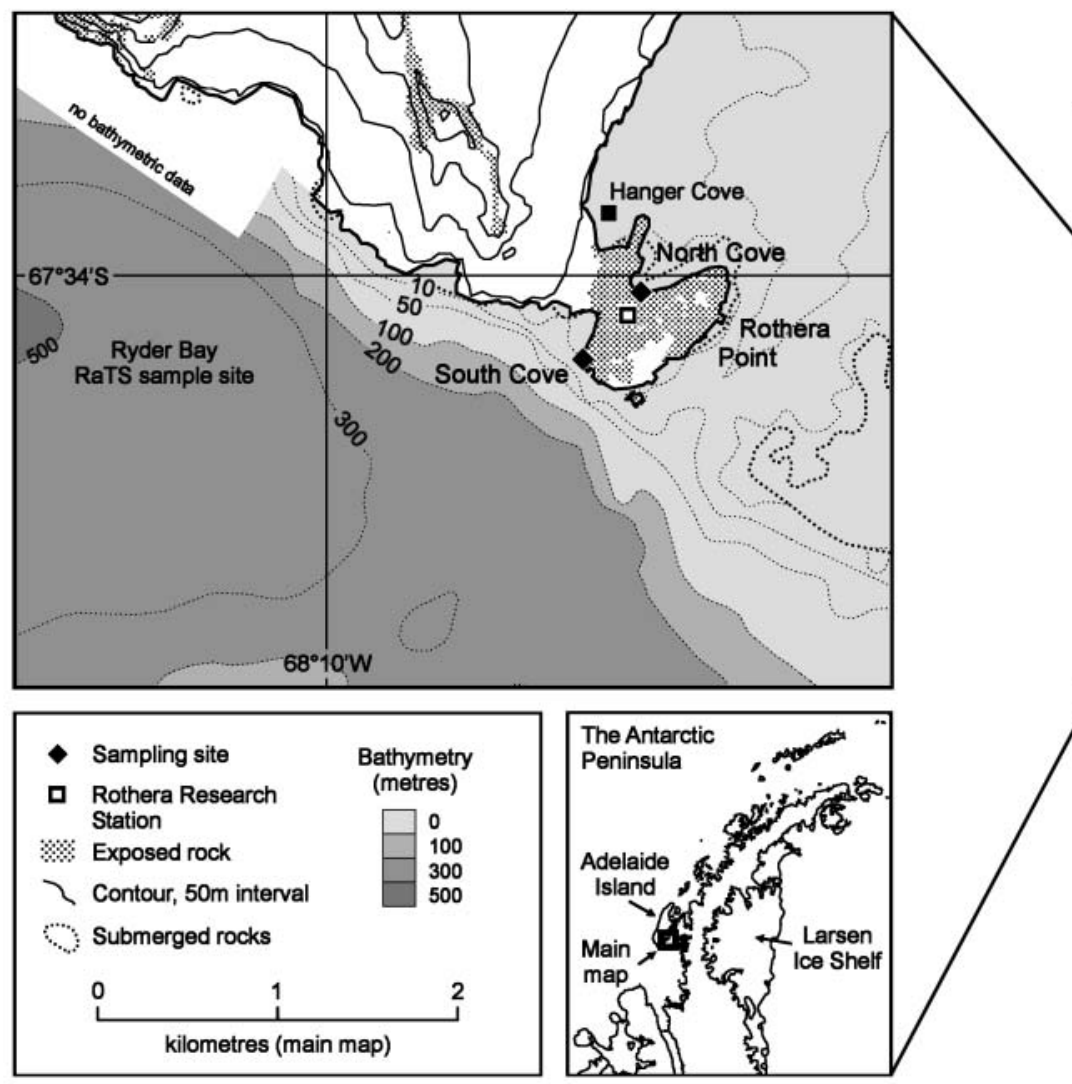

Fig 1. The British Antarctic Research Station, Rothera, Rothera Point, Adelaide Island to the west of the Antarctic Peninsula $\left(67^{\circ} 34^{\prime} \mathrm{S}\right.$, $\left.68^{\circ} 08^{\prime} \mathrm{W}\right)$

thermometer at $15 \mathrm{~m}$ depth), and pigment concentrations (chlorophyll $a$ and phaeophytin concentrations collected at $15 \mathrm{~m}$ with NIO or Niskin sampling bottles) in 20,5, 2 and $0.2 \mu \mathrm{m}$ size fractions from CTD casts to $200 \mathrm{~m}$ depth, and has been doing so since early 1997. A Rothera sediment trap has been situated on the south side of Trolval Island since November 1997 (Fig. 2). The trap is anchored to the bottom in $34 \mathrm{~m}$ of water, and hangs in mid water at $26 \mathrm{~m}$ collecting particulate matter as it falls through the water column.

Organ indices. The disc diameter of each individual was measured to an accuracy of $0.1 \mathrm{~mm}$ using vernier callipers. Where possible, the sex of the individuals was determined during dissection, males possessing a red, sac-like gonad, whereas the ovaries were spherical and yellow. The gonads of each individual were removed and stored in a $70 \%$ propan-2-ol solution. The wet weight of this tissue was also recorded for gonad index assessments. Disc diameter and disc depth was used to calculate disc volume, taking the disc to be circular. Many individuals had part of or all of an arm missing; therefore, a gross wet weight measure for gonad index was not possible. The gonad index was calculated by the following formula:

$$
\mathrm{GI}=(\mathrm{GW} \times 100) / \mathrm{DV}
$$

where GI = gonad index $(\%)$, GW = gonad mass $(g)$, and DV $=$ disc volume $\left(\mathrm{mm}^{3}\right)$.

Histological preparation. Each sample was dehydrated in three 2-hourly changes of $100 \%$ propan-2-ol then transferred to a clearing solution (Xylene) for $4 \mathrm{~h}$. Samples were impregnated in molten wax in a ther-

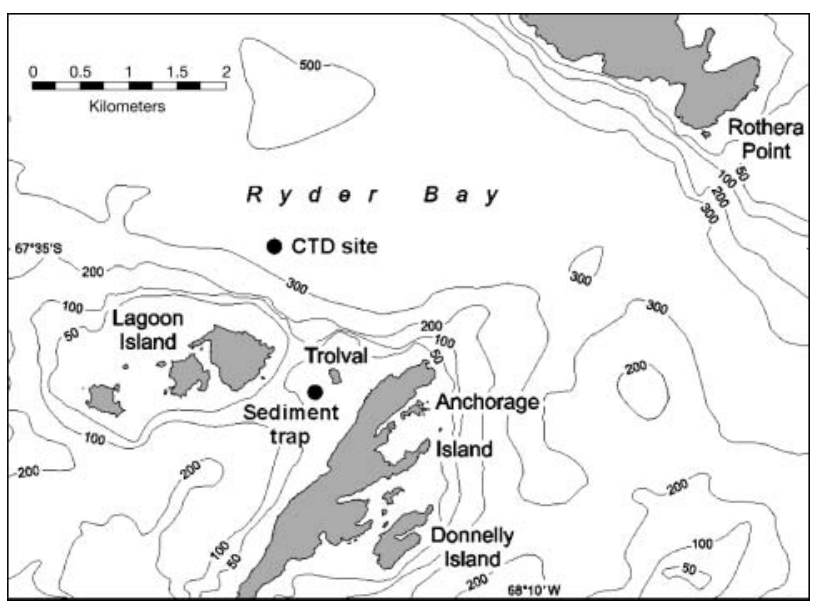

Fig. 2. The Rothera Time Series Water Sampling Programme (RaTS) CTD site and sediment trap anchored off Trolval Island, south of Rothera Point 
mally controlled oven $\left(70^{\circ} \mathrm{C}\right)$ for a period of 12 to $15 \mathrm{~h}$, after which all samples were wax embedded. All wax blocks were sectioned at $7 \mu \mathrm{m}$ on a standard microtome, where provision was made for duplicate slides to be produced for each sample. The tissue sections were mounted onto slides and stained with Haemotoxylin Z and Eosin (Cell Path UK). A DPX mountant was used to coverslip the slides.

Fecundity. Fecundity of Ophionotus victoriae was determined according to Sumida et al. (2000) from individuals collected during the months immediately before spawning. Individuals were dissected and all gonads counted. From each individual, 3 gonads were selected, to act as 1 sample and 2 replicates, respectively. Images were captured from ovarian smear preparations using the software package Rainbow Runner and the gametes counted using SigmaScan Pro4. The number of vitellogenic oocytes was obtained as a measure of the actual instantaneous fecundity (egg number per gonad $\times$ gonad number) and the overall average egg number in each individual taken to produce an average fecundity for each year. The fecundity data were corrected to a standard female (27 mm disc diameter). A measure of reproductive output was calculated from the percentage decrease in gonad index over the spawning period of each sample year, and applied to the 4 yearly egg counts to determine the approximate number of eggs spawned.

Oocyte image analysis. Images of each slide were captured using the software Rainbow Runner (Jandell Scientific Software) and the oocyte feret diameter $(\mu \mathrm{m})$ of at least 100 oocytes (where possible) from each individual measured using SigmaScan Pro4 (Jandell Scientific Software). The feret diameter calculates the diameter of each oocyte assuming the best-fit spherical size of the oocyte. Only oocytes possessing a nucleus were measured. Previtellogenic oocytes were smaller with a darkly stained, basophilic nucleus, whereas vitellogenic oocytes were larger, coarse looking and eosinophilic (Hendler 1991) (Fig. 3A).

Staging male maturity. Males were staged based upon the appearance and characteristics of the testes (Fig. 3B). Five stages were identified in this species, specific to criteria distinguishing differences in the quantity and distribution of spermatozoa in the testes.

Stage I: The testes are small and contain no spermatozoa. However, spermatocytes may be visible as a thin layer toward the periphery of the gonad.

Stage II: Spermatozoa have rapidly increased in number, occurring in clusters but eventually radiating out into rows. Some spermatozoa also line the lumen of the testes, where the peripheral spermatocyte layer has visibly shrunk.

Stage III: The testes have increased in size and the spermatocyte layer has reduced further in thickness. Spermatozoa extend to the lumen in chains and are rapidly generated.

Stage IV: Spermatozoa occupy the entire lumen and have significantly increased in number, explaining the increase in the size of the testes. Toward the end of this phase a whorl of spermatozoa develops, which arises from the remaining testicular mass, becomes separated and resides in the centre of the testes. The latter part of this stage precedes spawning.

Stage V: The testes are reduced in size and are similar in appearance to their immature Stage I, specifically in terms of a thin spermatocyte layer. The lumen may also contain undischarged spermatozoa.
A

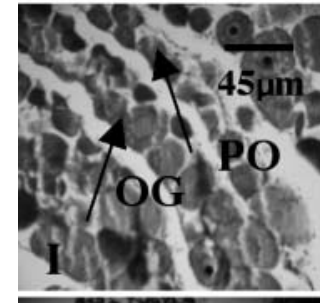

B

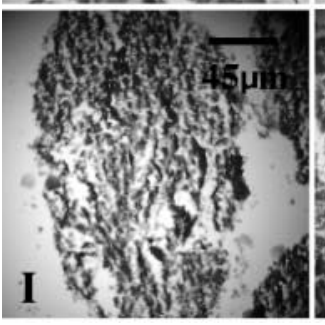

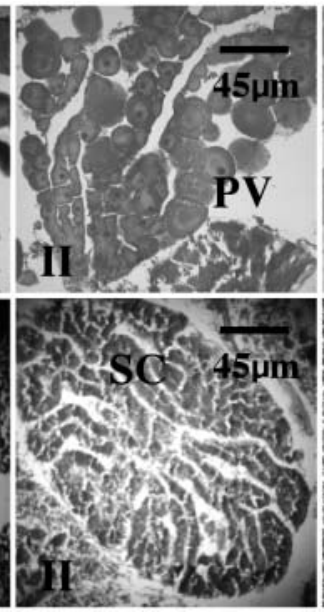
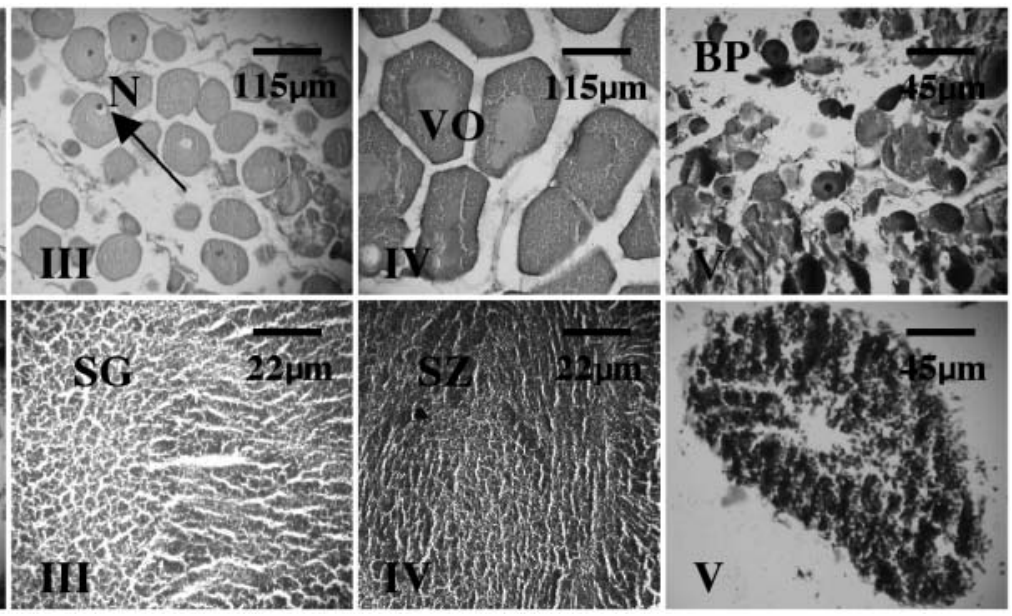

Fig. 3. Ophionotus victoriae. (A) Ovarian and (B) testes gonad sections and gametogenic stages (I-V). SC: spermatocytes; SG: spermatogonia; SZ: spermatozoa; OG: oogonia; PO: primary oocytes; PV: pre-vitellogenic oocytes; N: nucleus; VO: vitellogenic oocytes; BP: by-products 
Gut nutritional analysis. The gut tissue from 10 individuals from the austral winter, summer and spawning period from each sampling year (1997 to 2000) was dissected and wet weighed to calculate gut index (GtI):

$$
\mathrm{GtI}=(\mathrm{GtW} \times 100) / \mathrm{DV}
$$

where $\mathrm{GtW}=$ gut mass $(\mathrm{g})$; and $\mathrm{DV}=$ disc volume $\left(\mathrm{mm}^{3}\right)$.

Statistical analysis. Statistical manipulation followed the methods of Fowler et al. (1998) and, where appropriate, were carried out using Minitab 13.0.

\section{RESULTS}

\section{The physical environment}

Annual ice cover in Rothera was variable during 1997 to 2000, with greatest coverage during the austral winter of 1997. The extent of ice cover was much reduced in the following years of the study and the occurrence of ice in the latter period was patchy in comparison with the extent observed in 1997. Temperatures ranged between -1.89 and $1.42^{\circ} \mathrm{C}$ between June 1997 and February 1999, with an annual peak during January/February and a minimum during June/July (Fig. 4). The annual temperature cycle was closely tracked by the concentration of photosynthetic pigments in the waters around Rothera. Chlorophyll a concentrations ranged between $23 \mathrm{mg} \mathrm{m}^{-3}$ in February 1998 and <0.03 $\mathrm{mg} \mathrm{m}^{-3}$ in September 1997. Defined phytoplankton blooms were noticeable during the austral summers of 1998, 1999 and 2000: February $1998\left(23.28 \mathrm{mg} \mathrm{m}^{-3}\right)$, February $1999\left(13.42 \mathrm{mg} \mathrm{m}^{-3}\right)$, a series of peaks between December 1999 and February $2000\left(23.71,18.69,20.96\right.$ and $\left.20.04 \mathrm{mg} \mathrm{m}^{-3}\right)$. The phytoplankton blooms generally lasted for 8 to $10 \mathrm{wk}$. The sedimentation data were reliable in a comparative sense highlighting the relative differences between years. Sedimentation varied markedly between 1997 to 2000, with a remarkable peak during the austral summer of 1998 to 1999 (550 mg d $\left.{ }^{-1}\right)$. Moderate flux levels were observed in the summers prior to and proceeding this maximum event. The sedimentation

Table 1. Ophionotus victoriae. Sex ratio 1997 to 2000

\begin{tabular}{|lccc|}
\hline Year & Male & Female & Total ind. \\
\hline 1997 (Sep-Dec) & 28 & 12 & 40 \\
1998 & 73 & 46 & 119 \\
1999 & 51 & 49 & 100 \\
2000 & 56 & 62 & 118 \\
\hline
\end{tabular}

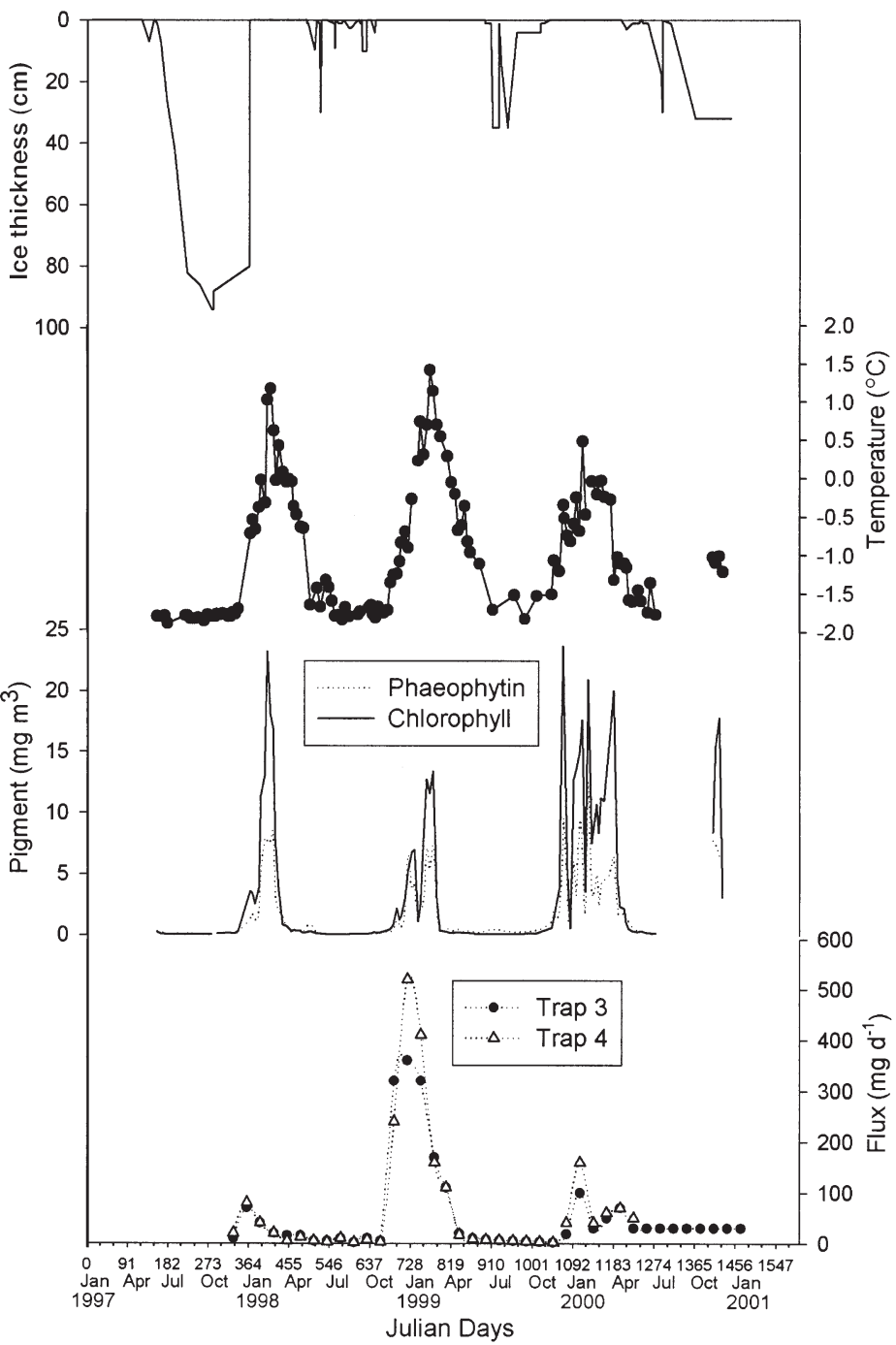

Fig. 4. Rothera Time Series Water Sampling Programme (RaTS) environmental data (1997-2000). Julian Day scale beginning from $1=1$ January 1997

events observed in 1998 to 1999 and 1999 to 2000 showed a wider coverage with periods of $240 \mathrm{~d}$ (September 1998 to May 1999) and 180 d (November 1999 to May 2000), respectively, compared to a much more limited period in 1997 to 1998 (91 di November 1997 to February 1998).

\section{Sex ratio and disc diameter of Ophionotus victoriae}

A total of 377 individuals were dissected of which $208(55 \%)$ were male and $169(45 \%)$ were female (Table 1). The sex ratio of the sampled population differed only slightly from a ratio of 1:1 with a marginal bias toward males $\left(\chi^{2}=4.04, p<0.05\right)$. Gender divisions between sampling years were significant 


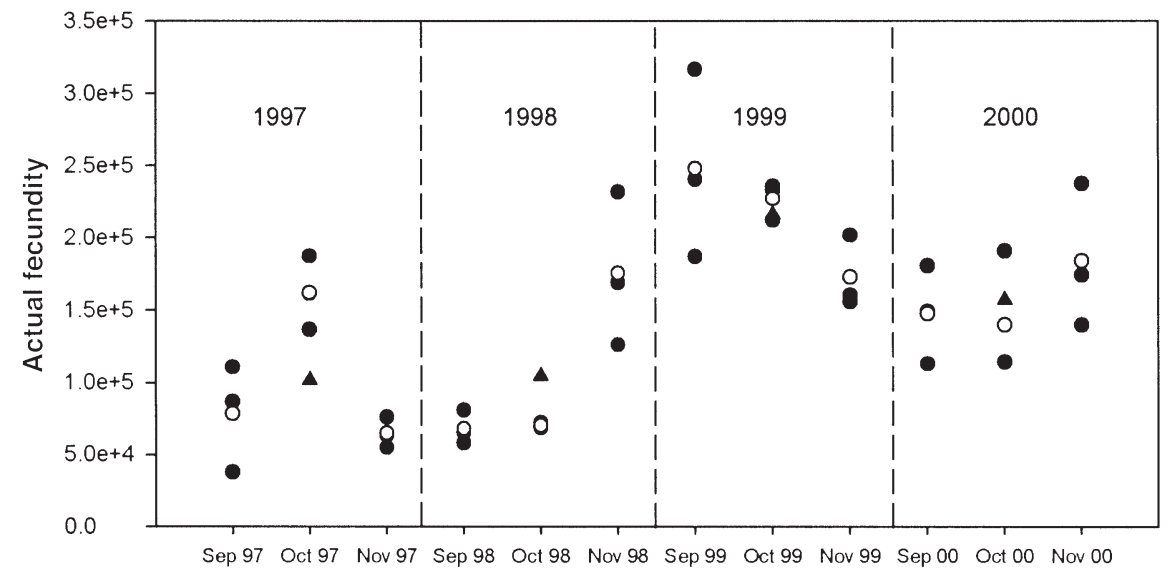

Fig. 5. Ophionotus victoriae. Annual fecundity data (1997-2000). Egg number per gonad $(\bullet)$; average egg number per indivudual $(0)$; and average egg number $\mathrm{yr}^{-1}(\mathbf{\Delta})$ $\left(\chi^{2}=8.93, \mathrm{p}=0.030\right)$. The prevalence of males was significant in the smaller sample population collected during the austral summer of September-December $1997\left(\chi^{2}=6.43, \mathrm{p}<0.05\right)$ and January-December 1998 $\left(\chi^{2}=6.13, \mathrm{p}<0.05\right)$. However, a ratio of $1: 1$ was seen in the population collected in 1999 and $2000\left(\chi^{2}=0.05\right.$ and $\chi^{2}=0.31, \mathrm{p}>0.05$ respectively).

Disc diameters ranged from 11.2 to $38.1 \mathrm{~mm}$ (mean = $26.46 \mathrm{~mm}, \mathrm{SD}=3.57, \mathrm{n}=378$ ). The larger range in disc diameter was recorded for the female population of Ophionotus victoriae with a minimum disc diameter of $11.2 \mathrm{~mm}$ and a maximum of $38.1 \mathrm{~mm}$ (mean $=27.0 \mathrm{~mm}$, $\mathrm{SD}=3.67, \mathrm{n}=169$ ). Male disc diameter ranged from $17.6 \mathrm{~mm}$ to a maximum of $34.9 \mathrm{~mm}$ (mean $=26.05 \mathrm{~mm}$, $\mathrm{SD}=3.47, \mathrm{n}=208$ ). The maximum disc diameter observed for both male and females exceeds the previous value reported for this species collected from the high Antarctic (32 mm) (Dahm 1999). The smallest individual with mature gonads in this study was an $11.2 \mathrm{~mm}$ female, which was recovered in October 2000. Therefore, the minimum size of this species at sexual maturity (in females) must be at least $11.2 \mathrm{~mm}$. The range of disc diameters between the male and female sample population did not differ significantly (Mann-Whitney, $W=36361.5, \mathrm{p}=0.005$ ). A 1 -way ANOVA of disc diameter confirmed a significant difference over the sample period within individual size $(F=5.21, \mathrm{p}<0.001)$.

\section{Fecundity}

The maximum actual fecundity observed was 248000 eggs in 1 ripe individual in 1999 (Fig. 5). However, mean fecundity varied from 100000 eggs ind. ${ }^{-1}$ during the ripest months of 1997 and 1998 and 220000 during the late austral spring of 1999. The average fecundity of Ophionotus victoriae in 2000 was 160000 eggs.
There was significant variability within actual fecundity (Fig. 5) over the 4 spawning periods (Kruskal-Wallis, $H=16.78, \mathrm{p}<0.001$ ). Differences were also observed when fecundities were compared between individual years (Table 2). The difference in actual fecundity in Ophionotus victoriae was largest between 1997 and 1999. In contrast, there was no significant difference between the fecundities observed in 1997 and 1998. The number of gonads was high and variable (80 to 240). Fecundity was disc diameter dependent $\left(\mathrm{r}^{2}=0.725, \mathrm{p}<0.05\right)$ (Fig. 6) and was scaled to a standard individual of $27 \mathrm{~mm}$ disc diameter (Fig. 7). For a standard female $(27 \mathrm{~mm}$ disc diameter) fecundity was highest in $1999(\sim 2.0 \times$ $10^{5} \pm 37570$ eggs), with a more modest accumulation of eggs in 1997 and $1998\left(1.1 \times 10^{5} \pm 42096\right.$ and $1.2 \times 10^{5} \pm 57963$ eggs). A standard female in 2000 produced approximately $1.5 \times 10^{5} \pm 36786$ eggs. The annual pattern in fecundity between 1997 and 2000 was uncoupled with the preceding chlorophyll maxima in the waters around Rothera; however, it was closely coupled with the magnitude of the preceding benthic sedimentation event (9 to 10 mo previously).

Table 2. Ophionotus victoriae. Fecundity and gonad index (GI) statistics. Mann-Whitney was used for all tests

\begin{tabular}{|lcc|}
\hline Year comparison & Test statistic $(W)$ & p-value \\
\hline $1997-1998$ fecundity & 85.0 & 1.0000 \\
$1997-1999$ fecundity & 50.0 & 0.0020 \\
$1997-2000$ fecundity & 60.0 & 0.0273 \\
$1998-1999$ fecundity & 52.0 & 0.0036 \\
$1998-2000$ fecundity & 61.0 & 0.0341 \\
$1999-2000$ fecundity & 112.0 & 0.0217 \\
$1997-1999$ GI & 1749.0 & 0.0001 \\
$1997-2000$ GI & 2034.0 & 0.0001 \\
$1998-1999$ GI & 10033.0 & 0.0001 \\
$1998-2000$ GI & 11088.0 & 0.0001 \\
\hline
\end{tabular}




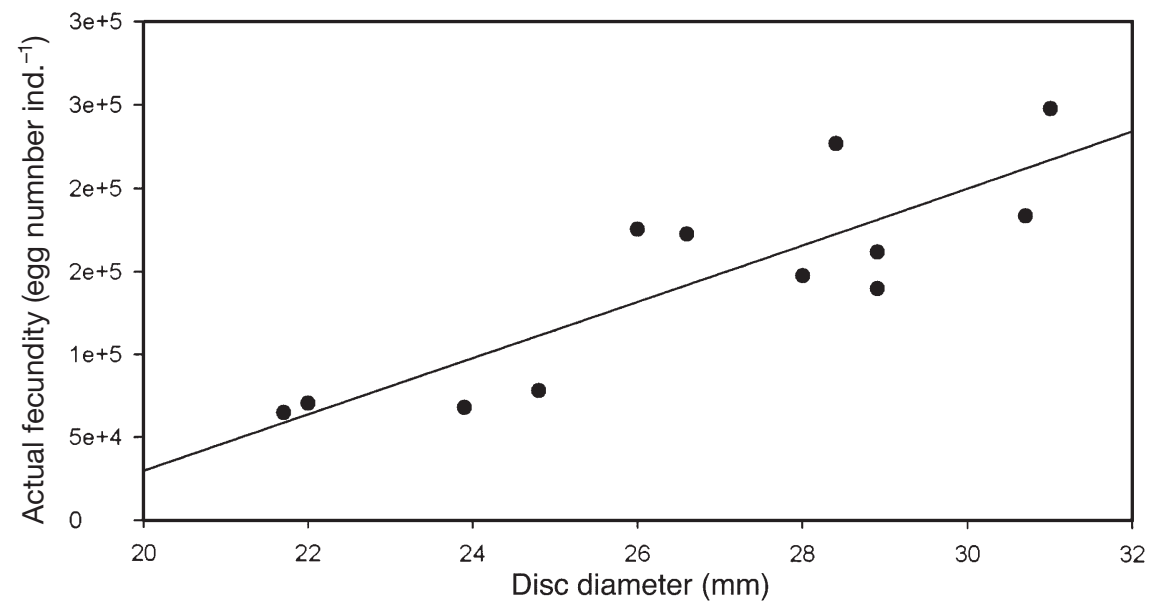

Fig. 6. Ophionotus victoriae. Correlation between individual fecundity and individual disc diameter $(\mathrm{mm}) ; \mathrm{r}^{2}=0.725$

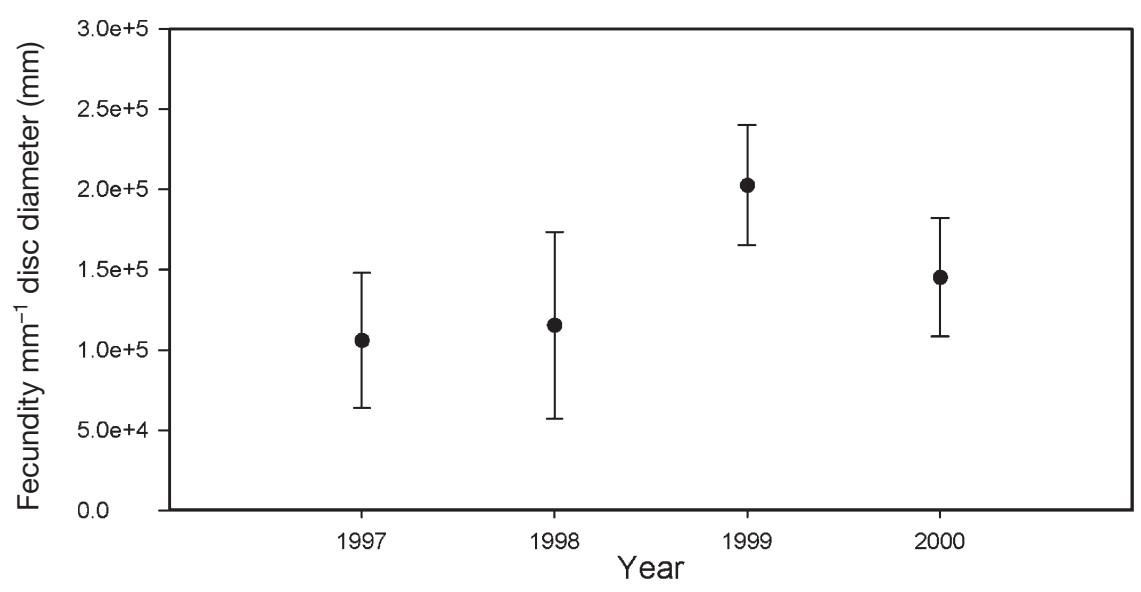

Fig. 7. Ophionotus victoriae. Annual fecundity $( \pm \mathrm{SD})$ for a standard female (27 $\mathrm{mm}$ disc diameter)

\section{Reproductive effort}

The gonad index showed significant inter-annual variation (Fig. 8). The testis index ranged from 0.0008 to 1.92 (mean $=0.23, \mathrm{SD}=0.30, \mathrm{n}=208$ ) in October 1998 and September 1999, respectively, whereas the ovary index ranged from 0.0078 to 1.55 (mean $=0.23$, $\mathrm{SD}=0.25, \mathrm{n}=169$ ) in January 1999 and October 2000, respectively. Four spawning events were apparent from the data, which were similar in their timing during November-December of each year, but differed markedly in magnitude between years. In November 1997 spawning was limited (12.5\% decrease), as no significant change in gonad index was evident (Fig. 8). A moderate peak in the index was observed a year later in 1998 (0.50) with a spawning event evident in December, indicated by a $90 \%$ reduction in the gonad index. Reproductive effort was high in 1999 (1.92) and
2000 (1.55), where a percentage decrease of 96 and $88.9 \%$ was observed in gonad index respectively.

There was synchrony in interannual variation in reproductive effort between the male and females (MannWhitney, $W=39083.0, \mathrm{p}=0.828$ ). However, there was a significant difference in the overall gonad index during the sampling period (KruskalWallis, $H=65.80$, p $<0.001)$. There was no significant difference between the gonad indices of 1997 and 1998 (Mann-Whitney, $W=3290.0, \mathrm{p}=$ 0.722 ) or between 1999 and 2000 (Mann-Whitney, $W=11781.0, \mathrm{p}=$ 0.074). However, significant differences were found between 1997 and 1999, 1997 and 2000, 1998 and 1999 and 1998 and 2000 (Table 2). The trend in gonad index was similar to fecundity variation during the study period and was associated with the preceding year's flux characteristics.

The reproductive output calculations allowed an estimate of the number of eggs spawned. According to the 12.5, 90, 96 and $88.9 \%$ decrease in gonad index over the spawning periods of 1997, 1998, 1999 and 2000, respectively, spawning was a magnitude greater in $1999\left(2 \times 10^{5}\right.$ eggs $)$ compared with the other years (Table 3). The number of eggs released in 1998 and 2000 was similar, with the lowest spawning event recorded in 1997.

\section{Oocyte feret diameter}

There was a marked intra- and inter-annual variation in average oocyte size (oocyte feret diameter) between 1997 and 2000 (Kruskal-Wallis, $H=511.99$, $\mathrm{p}<0.001$ ) (Fig. 9). Four spawning events were identified. The first was moderate and marked the release of oocytes in the late austral spring/early summer of 1997, where oocyte sizes decreased from an average of $105.7 \mu \mathrm{m}(\mathrm{SD}=40.1, \mathrm{n}=100)$ in September 1997 to $41.6 \mu \mathrm{m}(\mathrm{SD}=24.4, \mathrm{n}=509)$ in January 1998 . The maximum average oocyte size was observed in November $1998($ mean $=149.3 \mu \mathrm{m}, \mathrm{SD}=41.1, \mathrm{n}=341)$ followed by a large spawning event and a reduction in average oocyte size to $33.8 \mu \mathrm{m}(\mathrm{SD}=17.0, \mathrm{n}=616)$ in January 1999. This decrease in size translated to a 


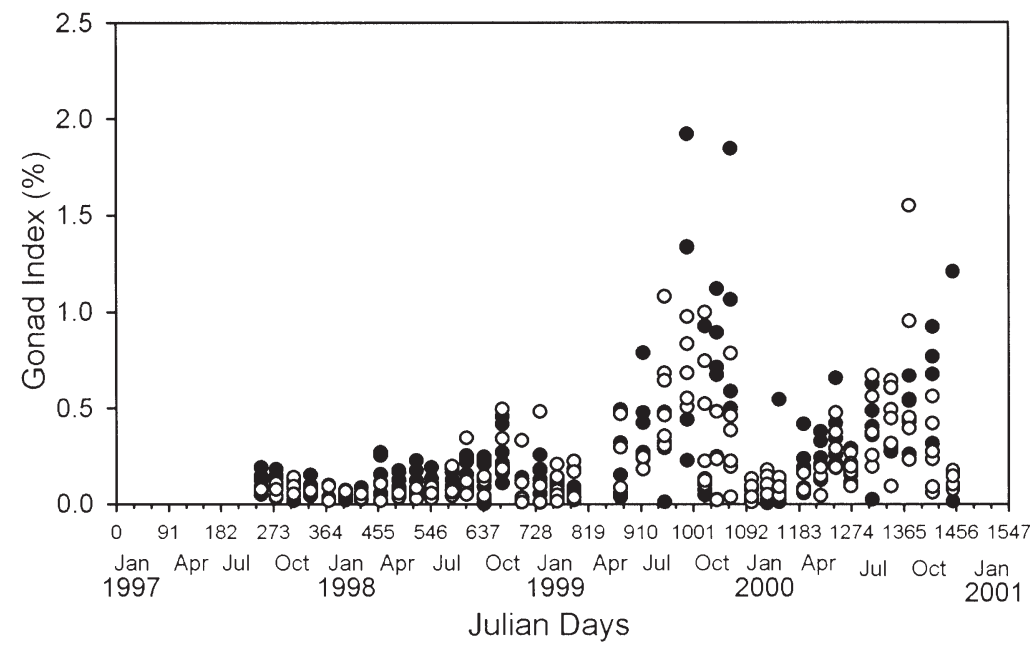

Fig. 8. Ophionotus victoriae. Annual male (•) and female (०) gonad index (1997-2000)

Table 3. Ophionotus victoriae. Reproductive output calculations

\begin{tabular}{|ccccc|}
\hline Year & $\begin{array}{c}\text { Gravid } \\
\text { fecundity }\end{array}$ & $\begin{array}{c}\% \\
\text { decrease }\end{array}$ & $\begin{array}{c}\text { Post-spawned } \\
\text { fecundity }\end{array}$ & $\begin{array}{c}\text { Spawned } \\
\text { eggs }\end{array}$ \\
\hline 1997 & $1.02 \mathrm{E}+5$ & 12.5 & $8.92 \mathrm{E}+4$ & $1.27 \mathrm{E}+4$ \\
1998 & $1.05 \mathrm{E}+5$ & 90 & $1.05 \mathrm{E}+4$ & $9.44 \mathrm{E}+4$ \\
1999 & $2.16 \mathrm{E}+5$ & 96 & $8.64 \mathrm{E}+3$ & $2.07 \mathrm{E}+5$ \\
2000 & $1.57 \mathrm{E}+5$ & 88.9 & $1.75 \mathrm{E}+4$ & $1.40 \mathrm{E}+5$ \\
& & & & \\
\hline
\end{tabular}

significant loss in gamete volume consistent with the decrease in gonad index. The average oocyte size increased during 1999 but only reached an average of 92.6 $\mathrm{mm}(\mathrm{SD}=33.5, \mathrm{n}=467$ ) in November 1999. Spawning followed this period, but only reduced the average oocyte size to $72.8 \mu \mathrm{m}(\mathrm{SD}=$ 32.7, $\mathrm{n}=464$ ) in January 2000. Average oocyte size increased to $128.4 \mu \mathrm{m}$ (SD = 39.6, $\mathrm{n}=681$ ) in November 2000 and declined until the end of the study period, consistent in timing with the other 3 spawning events.

The reproductive cycle had a long-term component additional to the seasonal signature described above (Fig. 10). This figure shows overlapping generations of oocytes. The first generation of previtellogenic oocytes has started developing before spawning of the preceding generation, which is especially clear in oocyte frequency data for October/November 1997. These data illustrate a bimodal distribution of oocyte sizes showing the presence of 2 cohorts and an 18 to 24 mo gametogenic cycle. Proportions of previtellogenic and vitellogenic oocytes varied significantly over the sampling period (Kruskal-Wallis, $H=$ 15.32, $\mathrm{p}=0.002$ ), suggesting a disparity between this animal and the constant proportions expected in a continuous reproducer. Ophionotus victoriae changed both oocyte number and average oocyte size each year emphasising the large inter-annual variation in the reproductive ecology of this animal.

\section{Male maturity}

The Male Maturity Index ranged between being spent and being at an immature gametogenic stage (I-II) during the austral summer of each year (Fig. 9). The latter was pronounced in January 2000, when testes were spent. The more mature stages (III-IV) were found as early as the late austral winter up until the spawning season. Male and female spawning was synchronous.

\section{Reproductive cycle}

Egg size was the only character that proved to be normal (Anderson-Darling normality test, A-squared = $0.521, \mathrm{p}=0.172$ ). Therefore, the data were ranked prior to performing correlations. Many environmental and biological parameters appeared correlated (Table 4). Temperature was the only environmental parameter that had a significant correlation with the mean maximum oocyte size (Pearsons Product Correlation,

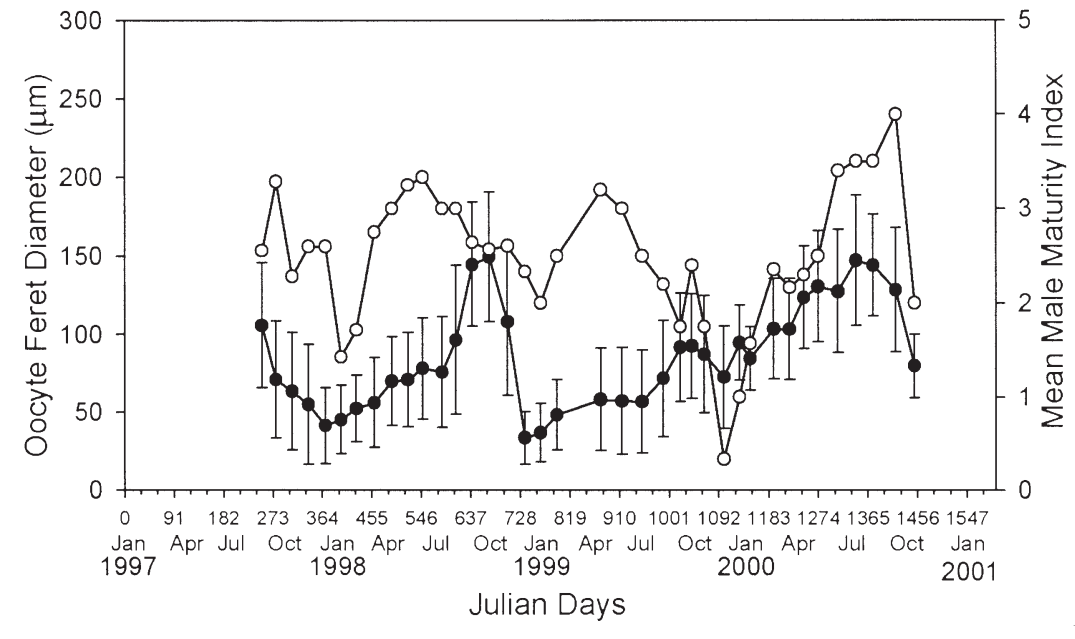

Fig. 9. Ophionotus victoriae. Annual female oocyte feret diameter (•) $( \pm \mathrm{SD})$ and male maturity stage $(0)$. Stage 5 is plotted as zero to convey the testes as spent 

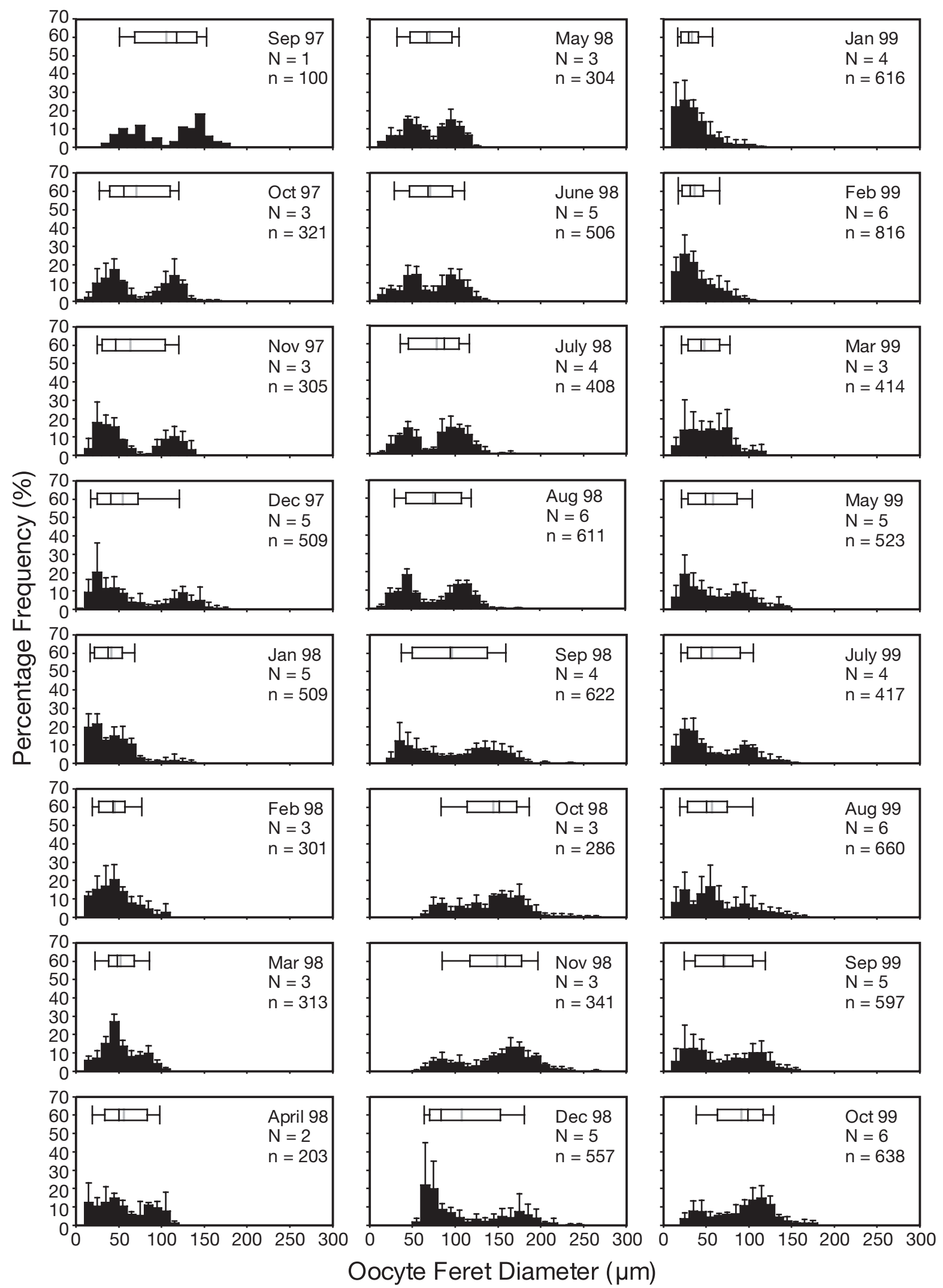

Fig. 10. (Above and following page.) Ophionotus victoriae. Oocyte feret diameter histograms $( \pm \mathrm{SD})$, where N: number of females; n: number of eggs counted (1997-2000) and monthly box plots covering the oocyte feret diameter range (the left and right hand limits of each box indicate the 25th and 75th percentiles; box whiskers indicate the 10th and 90th percentiles; the median (black line in box plot) and mean (grey line in box plot) of each oocyte range is also shown 

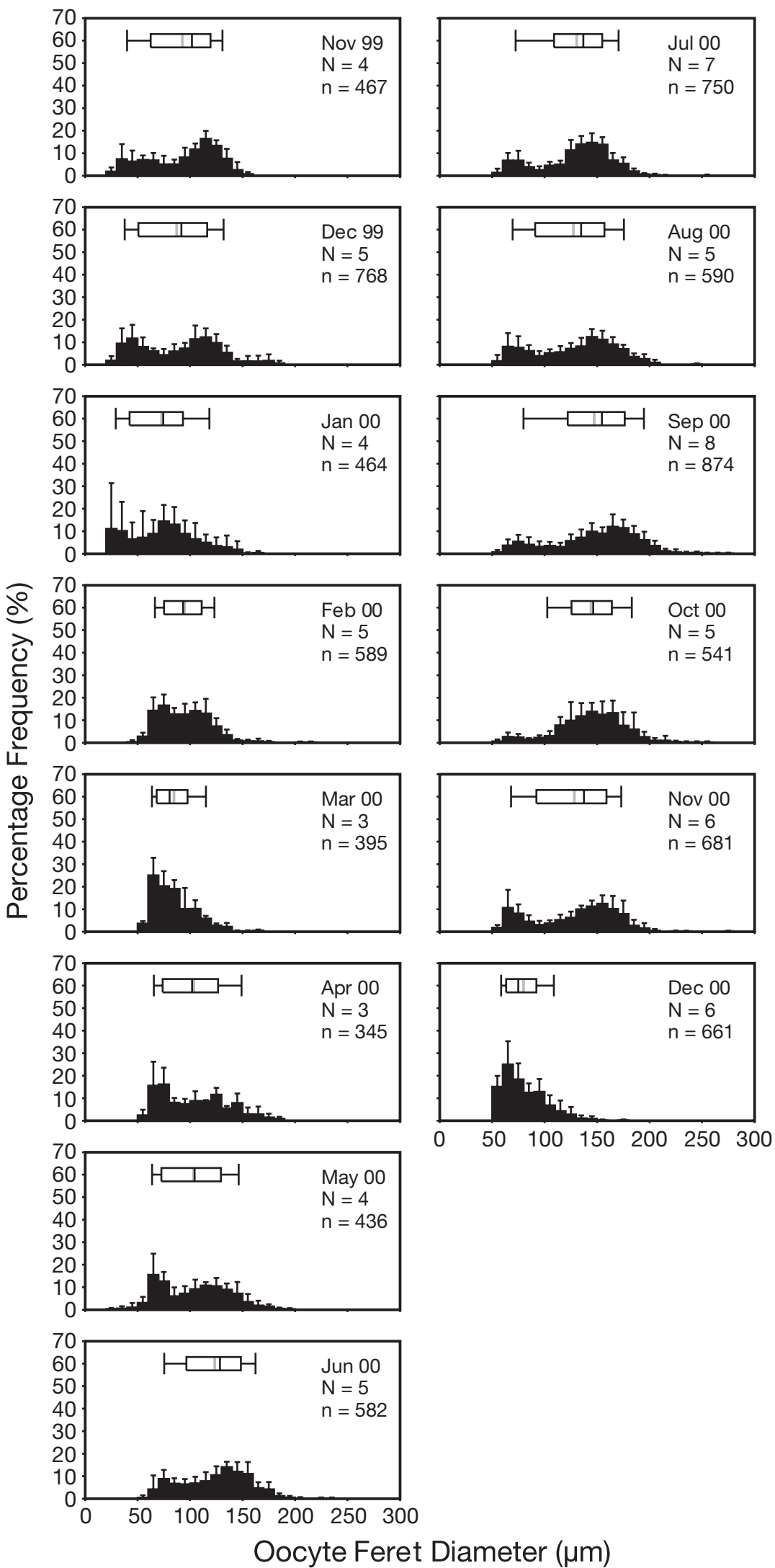

Fig. 10. (continued)
$-0.409, p=0.018)$, especially when the effect of chlorophyll was accounted for (Pearsons Product Correlation, $-0.520, \mathrm{p}=0.002)$. The relationship between the mean maximum oocyte size and all the environmental parameters combined (temperature and pigments) proved significant $(\mathrm{r}=5.84, \mathrm{p}=$ 0.006). This was also the case for gonad in$\operatorname{dex}(\mathrm{r}=4.97, \mathrm{p}<0.039)$.

\section{Nutritional condition}

Some inter-annual variation was evident in the gut index (Fig. 11) and followed a similar trend to gonad index over the $3 \mathrm{yr}$ sampling period, having 2 low-value years (1997-1998) and 2 higher-value years (1999-2000). There was a lag of approximately 3 mo between the peak GtI and peak GI. This was especially evident during 1999 and 2000. A marked decline was seen in the gut index during the spawning period of 1999 and 2000. We speculate that both gut and gonad indices may be driven by the previous season's sedimentation event at Rothera. This in turn compares well with trends in female fecundity, predisposing animals to a high fecundity following a good nutritional season and a reduced fecundity subsequent to a season of low organic flux.

\section{DISCUSSION}

\section{Sex ratio and disc diameter}

Ophionotus victoriae is dioecious. The sex ratio varied between years; however, overall it had a slight bias toward males. In dioecious ophiuroids the sex ratio is usually close to unity (Cuenot 1988, Hendler 1991). Deviation from unity may occur in dioecious ophiuroids as a result of differential recruitment, growth, mortality or sampling bias (Vevers 1953, Skjaeveland 1973). Size selective bias for larger individuals by divers cannot explain the marginal male prevalence in $O$. victoriae, as disc diameter was not found to be gender determined (Mann-Whitney, $W=36361.5, \mathrm{p}=0.005$ ). Therefore, we propose that an ecological explanation may be more reliable, e.g. individual aggregations or recruitment/ mortality factors. 
Table 4. Correlated environmental and biological variables

\begin{tabular}{|lcr|}
\hline Correlated variable & Test statistic & p-value \\
\hline Chlorophyll and phaeophytin & 0.910 & $<0.001$ \\
Temperature and chlorophyll & 0.747 & $<0.001$ \\
Temperature and phaeophytin & 0.695 & $<0.001$ \\
Gonad index and egg size & 0.500 & 0.003 \\
\hline
\end{tabular}

The smallest individual of Ophionotus victoriae examined was $11.2 \mathrm{~mm}$ disc diameter, and this individual was already developing gonads, suggesting early maturity in this species. The congeneric O. hexactis is similar, becoming sexually mature at 7 to $10 \mathrm{~mm}$, and is capable of brooding at $12 \mathrm{~mm}$ disc diameter (Morison 1979). The upper size range is similar in both species reaching a maximum diameter of $39 \mathrm{~mm}$ (Morison 1979, L. J. Grange pers. obs.).

\section{Reproductive effort}

All individuals had developing gonads. The gonad index increased throughout the austral winter and spring, peaking during October and November before decreasing during December. This cyclic pattern displayed considerable inter-annual variation between consecutive years. During 1997 and 1998 the gonad index was low whilst in the following years (1999 and 2000) the index was significantly higher. Similarly, the actual fecundity recorded for Ophionotus victoriae, which although variable, remained relatively high, ranged from $\sim 10^{5}$ eggs per standard female in 1997 to $>2.0 \times 10^{5}$ eggs in 1999. A direct relationship between reproductive effort and planktonic chlorophyll production could not be established. However, there was

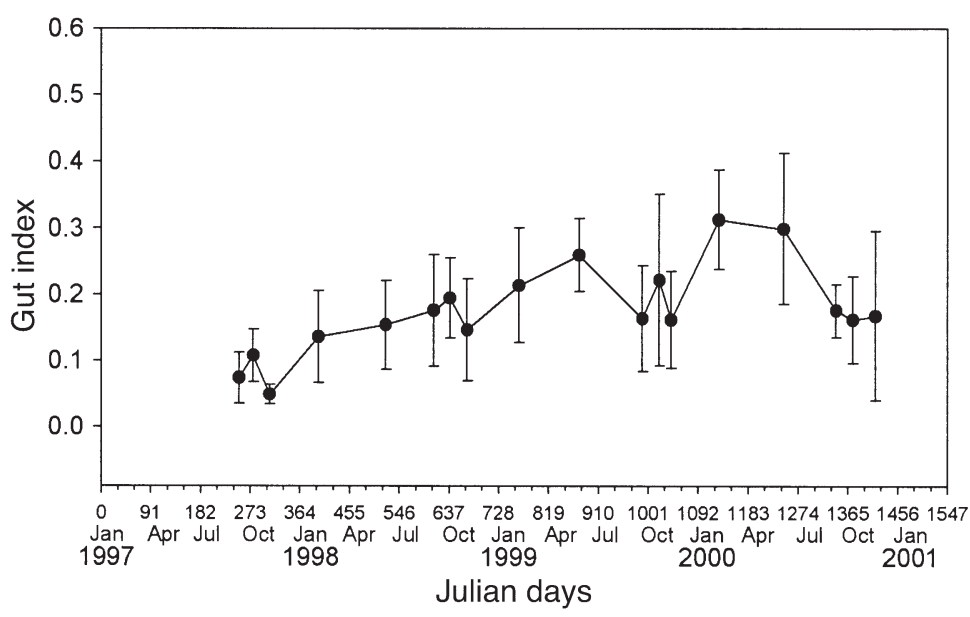

Fig. 11. Ophionotus victoriae. Annual gut index data (1997-2000) a connection between the sedimentation events at Rothera and ophiuroid reproductive characteristics. The magnitude and duration of each annual sedimentation event may play an important role in the following year's reproductive success. Patterns of ice cover and thickness probably modulate sedimentation, which then underpin reproductive effort in the following year.

\section{Oocyte frequencies}

This study is the first to examine the temporal variation in oocyte size frequencies of Ophionotus victoriae. Pearse (1994) reported a maximum oocyte size of $180 \mu \mathrm{m}$ for this brittle star, which compares with our average maximum oocyte size frequency of 170 to $190 \mu \mathrm{m}$. This relatively small oocyte size, coupled with the high fecundity of this species, indicates planktotrophy. Although most Antarctic larvae are pelagic lecithotrophs, some of the most abundant polar invertebrates produce planktotrophic larvae, and this trait is exhibited in 20 to $25 \%$ of polar echinoderms, including the asteroids Odontaster validus, Odontaster meridionalis and Porania antarctica (Pearse \& Bosch 1986, Bosch 1988, 1989) and the echinoid Sterechinus neumayeri (Bosch et al. 1987). The largest oocytes observed were around $250 \mu \mathrm{m}$. This may suggest a tendency towards a more adaptive development regime in Ophionotus victoriae. Larger egg sizes have been associated with a move to facultative planktotrophy associated with selection for larger juveniles, a shorter time for metamorphosis, a higher efficiency of fertilisation and insurance against fluctuations in phytoplankton abundance (Wray 1995). The incidence of facultative planktotrophy has been reported as present among some Antarctic ophiuroids (Hendler 1975) and may explain the extreme oocyte sizes recorded (Fig. 10).

Oocyte size also varied inter-annually. Egg sizes in echinoderms vary not only between populations, location and time, but also within the single spawn of a single female and between females (Emlet et al. 1987). Scientists working on January examples of Ophionotus victoriae in Terra Nova Bay, Ross Sea, recorded egg sizes twice as large as those recorded in this study (M. Chiantore pers. comm.). Lawrence (1991) associated such variability with a change in nutritional status and/or condition of the female. Additionally, it may be an adaptive response to unpredictable environments (Kaplan \& Cooper 1984, Travis 1984, Sibly et al. 1987). Scientific consensus tells us that 'good' years, in terms of resource availability, favour the production of a large number of small eggs, whereas a 'poor' year tends to see a few large eggs being pro- 
duced (reviewed by George et al. 1991). Small-egg strategists are more affected by changes in food ration, especially when resources are scarce (McEdward \& Miner 2003). Therefore, fecundity-time models tell us that when food is scarce fitness is low for small-egg strategies and increases with increasing egg size, whereas at higher food levels there is very high reproductive success for small-egg strategies. The resource input that arrives at the sea-bed and precedes the following reproductive event at Rothera presents patterns complementary to both patterns in egg size and reproductive effort, suggesting that resources provided by sedimentation may drive the reproductive characteristics in this brittle star. Temperature was the only environmental variable to correlate significantly with oocyte size. Benoît \& Pepin (1999) attributed this apparent effect to the way in which temperature interacts with maternal contributions to egg size, where maternal contributions are themselves partly ration dependent.

\section{Gametogenic cycle}

There were 2 distinct cohorts of oocytes maturing in the ovary at any one time throughout the study period. This pattern appears in a number of Antarctic seasonal breeders that have a period of gametogenic development between 18 and 24 mo (Pearse 1965, Brockington et al. 2001, Powell et al. 2001). This pattern has been observed in Odontaster validus from McMurdo Sound populations (Pearse 1965) and Sterechinus neumayeri (Pearse \& Cameron 1991, Brockington et al. 2001) as well as in deep-sea echinoids (Tyler \& Gage 1984). Other Antarctic taxa with long gametogenic development times include the brachiopod Liothyrella uva (Meidlinger et al. 1998), the amphipod Bonallia gigantea (>12 mo) and Kidderia subquadratum (15 to $19 \mathrm{mo}$ ) (reviewed by Clarke 1988) although the scallop Adamussium colbecki exhibits a discrete 12 mo cycle (Tyler et al. 2003). The data suggest that oocyte development is progressive, developing slowly initially and increasing rapidly prior to spawning when chlorophyll levels in the water column are increasing and much of the sedimented organics have been assimilated. The latter is described as an autosynthetic strategy of egg development (Eckelbarger 1994) and was also observed in O. validus (Pearse 1965).

\section{Reproductive and spawning cycles}

There was no significant difference between the gonad index of the males and females of the sample population indicating synchrony of reproduction.
Reproductive synchrony between male and female invertebrates has been documented in the Antarctic before, e.g. Odontaster validus (Pearse 1965), Adamussium colbecki (Tyler et al. 2003) and in the deep sea (Tyler 1988, Eckelbarger \& Watling 1995).

Spawning occurred annually during November and December. A similar spawning occurred in the circumpolar Antarctic echinoid Sterechinus neumayeri, where Brockington (2001) documented spawning between November and January during 1997 and 1998 in the North Cove population of this species.

\section{Nutritional condition}

The strong seasonality of the water column chlorophyll biomass recorded at Rothera is likely to have important implications for benthic feeding rates both for suspension feeders, via vertical flux, but also for generalists and deposit feeders depending on fixation and remineralisation rates (Brockington et al. 2001). However, our data indicate that the bloom itself is not indicative of resource availability, because sedimentation appears more important. Kellogg \& Kellogg (1982) referred to the acquisition of sediment by Ophionotus victoriae and reviewed its implications on sediment reworking. The small but evident peak in gut index recorded in 1998 during September and October may be attributed to the break up of winter fast ice in Ryder Bay and the initiation of a benthic bloom, a feature observed previously at Signy Island (Gilbert 1991), and exploited by the echinoid Sterechinus neumayeri (Brockington et al. 2001). The significant decline in the gut index during September-November 1999 and 2000 can be attributed to a diversion of energy into reproductive effort. Ophiuroids may find it difficult to feed when gravid owing to the space occupied by the gonads in the disc.

\section{Inter-annual variation}

Recent evidence suggests inter-annual signatures to be important not only within the Antarctic invertebrates, but within marine communities worldwide. The El Niño Southern Ocean Oscillation (ENSO) modifies the physico-chemical and biological signatures of the Pacific Ocean every few years (Navarrete et al. 2002, Wong et al. 2002) and the effect may extend to the Southern Ocean (Dayton 1989, Meredith et al. in press). A similar forcing has been recently identified in the Antarctic as the 'Antarctic Circumpolar Wave' characteristic of a 4 to $5 \mathrm{yr}$ cycle influencing both biological and environmental parameters (White \& Peterson 1996). 
The potential of further global climate change has important implications for the western Antarctic Peninsula, which has undergone the most rapid warming of any region in the Southern Hemisphere (King 1994, King \& Harangozo 1998), with mean annual temperatures increasing by more than $2.5^{\circ} \mathrm{C}$ over the last $50 \mathrm{yr}$.

This study presents strong inter-annual variability in an Antarctic marine invertebrate. We believe there are 3 main aspects to the reproductive ecology of Ophionotus victoriae: (1) The timing of each spawning event is the same between consecutive years (1997 to 2000) and between males and females during November/December, with brittle stars becoming spent in January; (2) the synchronous longer term oogenic cycle underlying the annual seasonal cycle (18 to $24 \mathrm{mo}$ ); and (3) the obvious inter-annual variability in reproductive effort, which can be connected with the extent and magnitude of the preceding organic sedimentation event. Subsidiary effects may have also been felt from the seasonal ice profile and temperature signal. A combination of all or some of these patterns may be an adaptation to the strong seasonality and low level resource supply characteristic of the Antarctic. The plasticity of this species and its ability to reproduce despite dramatic interannual variation in food supply and the variability in the physical components of the environment may explain why $O$. victoriae is a dominant member of the Antarctic benthos and a useful barometer for change.

Acknowledgements. We wish to thank all the British Antarctic Survey Rothera Scuba Diving team for collecting our animals, and the marine assistants, A. Chapman, J. Beaumont and R. Piper, for preserving specimens. Thanks go to A. Clarke for providing the environmental Rothera data (RaTs) and for all his helpful comments and support. We acknowledge a grant to L.J.G. from the Natural Environmental Research Council and her CASE partner the British Antarctic Survey.

\section{LITERATURE CITED}

Arnaud PM, Lópoz CM, Olaso I, Ramil F, Ramora-Esplá AA, Ramos A (1998) Semi-quantitative study of macrobenthic fauna in the region of the South Shetland Islands and the Antarctic Peninsula. Polar Biol 19:160-166

Benoît HP, Pepin P (1999) Interaction of rearing temperature and maternal influence on egg development rates and larval size at hatch in yellow tail flounder (Pleuronectes ferrgineus). Can J Fish Aquat Sci 56:785-794

Bosch IM (1988) Reproduction and development of asteroids and an echinoid in shallow waters of McMurdo Sound, Antarctica. PhD thesis, University of California, Santa Cruz, CA

Bosch IM (1989) Contrasting modes of reproduction in two Antarctic asteroids in the genus Porania, with a description of unusual feeding and non-feeding larval types. Biol Bull (Woods Hole) 177:77-82

Bosch IM, Beauchamp KA, Steele ME, Pearse JS (1987)
Development, metamorphosis, and seasonal abundance of embryos and larvae of the Antarctic sea urchin Sterechinus neumayeri. Biol Bull (Woods Hole) 173:126-135

Brockington S (2001) The seasonal ecology and physiology of Sterechinus neumayeri (Echinodermata: Echinoidae) at Adelaide Island, Antarctica. PhD thesis, British Antarctic Survey, Cambridge

Brockington S, Clarke A, Chapman ALG (2001) Seasonality of feeding and nutritional status during the austral winter in the Antarctic sea urchin Sterechinus neumayeri. Mar Biol 139:127-138

Byrne M (1994) Ophiuroidea: In Harrison FW, Frederick W (eds) Microscopic anatomy of invertebrates: Echinodermata, Vol 14. Wiley-Liss, New York, p 248-343

Chia FS (1974) Classification and adaptive significance of developmental patterns in marine invertebrates. Thalassia Jugosl 10:121-130

Chiantore M, Cattaneo-Vietti R, Elia L, Guidetti M, Antonini M (2002) Reproduction and condition of the scallop Admussium colbecki (Smith 1902), the sea urchin Sterechinus neumayeri (Meissner 1900) and the sea-star Odontaster validus (Koehler 1911) at Terra Nova Bay (Ross Sea): different strategies related to inter-annual variations in food availability. Polar Biol 25:251-255

Clarke A (1982) Temperature and embryonic development in polar marine invertebrates. Int J Invertebr Reprod 5(1): $71-82$

Clarke A (1988) Seasonality in the Antarctic marine environment. Comp Biochem Physiol Part B 90:461-473

Clarke A, Leakey RJG (1996) The seasonal cycle of phytoplankton, macronutrients and the microbial community in a nearshore Antarctic marine ecosystem. Limnol Oceanogr 41(6):1281-1294

Clarke A, Holmes LJ, White MG (1988) The annual cycle of temperature, chlorophyll and major nutrients at Signy Island South Orkney Islands 1969-1982. Br Antarct Surv Bull 80:65-86

Cuénot L (1988) Etudes anatomiques et morphologiques sur les Ophiures. Arch Zool Exp Gen 6:33-82

Dahm C (1996) Ecology and population dynamics of Antarctic ophiuroids (Echinodermata). Ber Polar- Meeresforsch 194: $1-289$

Dahm C (1999) Ophiuroids (Echinodermata) of southern Chile and the Antarctic: taxonomy, biomass, diet and growth of dominant species. Sci Mar 63(Suppl 1):427-432

Dayton PK (1989) Inter-decadal variation in an Antarctic sponge and its predators from oceanographic climate shifts. Science 245(4925):1484-1486

Dayton PK (1990) Polar benthos. In: Smith WO (ed) Polar oceanography, Part B. Chemistry, biology and geology. Academic Press, London, p 631-685

Dearborn JH (1977) Foods and feeding characteristics of Antarctic asteroids and ophiuroids. In: Llano GA (ed) Adaptations within Antarctic ecosystems. Proceedings of the Third SCAR Symposium on Antarctic Biology, 3rd, Smithsonian Institution. Gulf Publishing, Washington, DC, p 293-326

Eckelbarger KJ (1994) Diveristy of metazoan ovaries and vitellogenic mechanisms: implications for life history theory. Proc Biol Soc Wash 107(1):193-218

Eckelbarger KJ, Watling L (1995) Role of phylogenetic constraints in determining reproductive patterns in deep-sea invertebrates. Invertebr Biol 114:256-269

Emlet RB, McEdward L, Strathmann RR (1987) Echinoderm larval ecology viewed from the egg. In: Jangoux $M$, Lawrence JM (eds) Echinoderm studies, 2. AA Balkema, Rotterdam, p 55-137 
Emson RH (1999) Making the best of it: the ecology of deep sea echinoderms. In: Candia Carnevali MD, Bonasaro F (eds) Echinoderm research 1998. AA Balkema, Rotterdam, p 452

Fowler J, Cohen L, Jarvis P (1998) Practical statistical for field biology. John Wiley \& Sons, New York

Fratt DB, Dearborn JH (1984) Feeding biology of the antarctic brittle star Ophiontus victoriae (Echinodermata: Ophiuroidea). Polar Biol 3:127-139

Gage JD, Brey T (1994) P/B ratios in deep-sea brittle stars. In: David B, Guille A, Fèral JP, Roux M (eds) Echinoderms through time. AA Balkema, Rotterdam, p 421-426

George SB, Lawrence JM, Fenaux L (1991) Effect of food ration on egg quality of the starfish Luidia clathrata. Invertebr Reprod Dev 20:237-242

Giese AC (1959) Comparative physiology: annual reproductive cycles of marine invertebrates. Annu Rev Physiol 21: 547-576

Gilbert NS (1991) Primary production by benthic microalgae in nearshore marine sediments of Signy Island, Antarctica. Polar Biol 11:339-346

Hadfield MG, Strathmann MF (1996) Variability, flexibility and plasticity in life histories of marine invertebrates. Oceanol Acta 19(3/4):323-334

Hedgpeth JW (1971) Perspectives in benthic ecology in Antarctica. In: Quam LO, Porter D (eds) Research in the Antarctic. A symposium. American Association for the Advancement of Science, Washington, DC, p 93-136

Hendler G (1975) Adaptational significance of patterns of ophiuroid development. Am Zool 15:691-715

Hendler G (1991) Echinodermata: Ophiuroidea. In: Giese AC, Pearse JS, Pearse VB (eds) Reproduction of marine invertebrates, Vol VI. Echinoderms and lophoporates. Boxwood Press, Pacific Grove, CA, p 355-511

Hoegh-Guldberg O, Pearse JS (1995) Temperature, food availability and the development of marine invertebrate larvae. Am Zool 35:415-425

Kaplan RH, Cooper WS (1984) The evolution of developmental plasticity in reproductive characteristics: an application of the 'adaptive coin flipping' principle. Am Nat 123: 393-410

Kellog DE, Kellog TB (1982) Diatoms from brittle star contents: implications for sediment reworking. Antarct J US 17(5):167-169

King JC (1994) Recent climate variability in the vicinity of the Antarctic Peninsula. Int J Climatol 14:357-369

King JC, Harangozo SA (1998) Climate change in the western Antarctic Peninsula since 1945: observations and possible causes. Ann Glaciol 27:571-575

Koehler R (1912) Echinoderms. Report of the 11th Expedition: Antarct. Francise. Mason et Cie, Paris

Lawrence J (1991) Analysis of characteristics of echinoderms associated with stress and disturbance. In: Yanagisawa T, Yasumasu I, Oguro C, Suzuki N, Motokawa T (eds) Biology of Echinodermata. AA Balkema, Rotterdam, p 11-26

Lipps JH, Hickman CS (1982) Origin, age and evolution of Antarctic and deep-sea faunas. In: Ernst WG, Morin JG (eds) The environment of the deep-sea. Prentice-Hall, Eagle Wood Cliffs, NJ, p 324-356

Madsen FJ (1967) Ophiuroidea. British and Australian NZ Antarctic Research Expedition 1929-1931. Rep Adelaide (Ser B Zool Bot) 9(3):123-145

Manjón-Cabeza ME, Ramos A (2003) Ophiuroid community structure of the South Shetland Islands and Antarctic Peninsula region. Polar Biol 26:691-699

McEdward LR, Miner BG (2003) Fecundity-time models of reproductive strategies in marine benthic invertebrates: fitness differences under fluctuating environmental conditions. Mar Ecol Prog Ser 256:111-121

McGinley MA, Temme DH, Geber MA (1987) Parental investment in offspring in variable environments: theoretical and empirical considerations. Am Nat 130(3):370-398

Meidlinger K, Tyler PA, Peck LS (1998) Reproductive patterns in the Antarctic brachiopod Liothyrella uva. Mar Biol 132: 153-162

Meredith MP, Clarke A, Renfrew IA, King JC (in press) Anomalous upper-ocean characteristics in Marguerite Bay, western Antarctic Peninsula, in response to the 1997/8 ENSO. J Geophys Res

Mileikovsky SA (1971) Types of larval development in marine bottom invertebrates their distribution and ecological significance: a re-evaluation. Mar Biol 10:193-213

Morison GW (1979) Studies on the ecology of the Sub-Antarctic ophiuroid Ophionotus hexactis. PhD thesis, University of London, London

Mortensen Th (1936) Echinoidea and Ophiuroidea. Discov Rep 12:199-348

Navarrete SA, Broitman B, Wieters EA, Finke GR, Venegas RM, Sotomayor A (2002) Recruitment of intertidal invertebrates in the southeast Pacific: interannual variability and the 1997-1998 El Niño. Limnol Oceanogr 47(3):791-802

Pearse JS (1965) Reproductive periodicities in several contrasting populations of Odontaster valius, Koehler, a common Antarctic asteroid. Antarct Res Ser 5:39-85

Pearse JS (1994) Cold-water echinoderms break 'Thorson's Rule'. In: Young CM, Eckelberger KJ (eds) Reproduction, larval biology and recruitment of the deep-sea benthos. Columbia University Press, New York, p 26-43

Pearse JS, Bosch IM (1986) Are the feeding larvae of the commonest Antarctic asteroid really demersal? Bull Mar Sci 39:477-484

Pearse JS, Bosch IM (1994) Brooding in the Antarctic: Ostergren had it nearly right. In: David B, Guille A, Fèral JP, Roux M (eds) Echinoderms through time. AA Balkema, Rotterdam, p 111-120

Pearse JS, Cameron RA (1991) Echinodermata: Echinoidea. In: Geise AC, Pearse JS, Pearse VB (eds) Reproduction of marine invertebrates VI. Echinoderms and Lophophorates. Boxwood Press, Pacific Grove, CA, p 514-662

Pearse JS, McClintock JB, Bosch IM (1991) Reproduction of Antarctic benthic invertebrates: tempos, modes, and timing. Am Zool 31:65-80

Peck LS, Conway LZ (2000) The myth of metabolic cold adaptation: oxygen consumption in stenothermal Antarctic bivalves. In: Harper EM, Taylor JD, Crame JA (eds) The evolutionary biology of the Bivalvia, Vol 177. Geological Society, London, p 441-450

Pörtner HO (2002) Climate variations and the physiological basis of temperature dependent biogeography: systemic to molecular hierarchy of thermal tolerance in animals. Comp Biochem Physiol A 132:739-761

Pörtner HO, Hardewig I, Sartoris FJ, Van Dijk PLM (1999) Intracellular $\mathrm{pH}$ and energy metabolism in the highly stenothermal Antarctic bivalve Limopsis marionensis as a function of ambient temperature. Polar Biol 22:17-30

Powell DK, Tyler PA, Peck LS (2001) Effect of sperm concentration and sperm ageing on fertilization success in the Antarctic soft shelled clam Laternula elliptica and the Antarctic limpet Nacella concinna. Mar Ecol Prog Ser 215: 191-200

Sáiz-Salinas JL, Ramos A, Garcia FJ, Troncoso JS, San Martin G, Sánz C, Palacin C (1997) Quantitative analysis of macrobenthic soft-bottom assemblages in South Shetland waters (Antarctica). Polar Biol 17:393-400 
Sibly R, Calow P, Smith RH (1987) Optimal size of seasonal breeders. J Theor Biol 133:13-21

Skjaeveland SH (1973) Ecology of echinoderms in Borgenfjorden, North Trodelag, Norway. K Nor Vidensk Selsk Mus Misc 8:1-51

Stanwell-Smith DP, Peck LS, Clarke A, Murray AWA, Todd CD (1999) The distribution, abundance and seasonality of pelagic marine invertebrate larvae in the maritime Antarctic. Phil Trans R Soc Lond B 354:471-484

Sumida PYG, Tyler PA, Lampitt RS, Gage JD (2000) Reproduction, dispersal and settlement of the bathyal ophiuroid Ophiocten gracilis in the NE Atlantic Ocean. Mar Biol 137: 623-630

Thorson G (1950) Reproduction and larval development of marine bottom invertebrates. Biol Rev 25:1-45

Travis J (1984) Anuran size of metamorphosis: experimental test of a model based on intraspecific competition. Ecology 65:1155-1160

Tyler PA (1988) Seasonality in the deep sea. Oceanogr Mar Biol Annu Rev 26:227-258

Tyler PA, Gage JD (1984) The reproductive biology of

Editorial responsibility: Roger Hughes (Contributing Editor),

Bangor, UK echinothuriid and cidarid sea urchins from the deep sea (Rockall Trough, North-East Atlantic Ocean). Mar Biol 80(1):63-74

Tyler PA, Reeves S, Peck LS, Clarke A, Powell D (2003) Seasonal variation in the gametogenic ecology of the Antarctic scallop Adamussium colbecki. Polar Biol 26(11):727-733

Vaughan DG, Marshall GJ, Connelly WM, King JC, Mulvaney R (2001) Devil in the detail. Science 293:1777-1779

Vevers HG (1953) The biology of Asterias rubens L. IV. Variation in sex ratio. J Mar Biol Assoc UK 31:35-40

White WB, Peterson RG (1996) An Antarctic circumpolar wave in surface pressure, wind, temperature and sea ice extent. Nature 380:699-702

Wong CS, Waser NAD, Nojiri Y, Johnson K, Whitney FA, Page JS, Zeng J (2002) Seasonal and interannual variability in the distribution of surface nutrients and dissolved inorganic carbon in the Northern North Pacific: influence of El Niño. J Oceanogr 58:227-243

Wray GA (1995) Evolution of larvae and development modes. In: McEdward L (ed) Ecology of marine invertebrate larvae. CRC Press, Boca Raton, FL, p 79-122

Submitted: September 24, 2003; Accepted: April 14, 2004 Proofs received from author(s): August 12, 2004 